\title{
Recent Archeological Investigations at the Jewett Mine, East- Central Texas
}

Ross C. Fields

Prewitt and Associates, Inc.

Follow this and additional works at: https://scholarworks.sfasu.edu/ita

Part of the American Material Culture Commons, Archaeological Anthropology Commons, Environmental Studies Commons, Other American Studies Commons, Other Arts and Humanities Commons, Other History of Art, Architecture, and Archaeology Commons, and the United States History Commons

Tell us how this article helped you.

This Article is brought to you for free and open access by the Center for Regional Heritage Research at SFA ScholarWorks. It has been accepted for inclusion in Index of Texas Archaeology: Open Access Gray Literature from the Lone Star State by an authorized editor of SFA ScholarWorks. For more information, please contact cdsscholarworks@sfasu.edu. 


\section{Recent Archeological Investigations at the Jewett Mine, East-Central Texas}

Creative Commons License

(c) (i) (8)

This work is licensed under a Creative Commons Attribution-NonCommercial 4.0 International License 
RECENT ARCHEOLOGICAL INVESTIGATIONS AT THE JEWETT MINE, EAST-CENTRAL TEXAS

Ross C. Fields

The Jewett Mine is a ca. 21,000-acre lignite mine in the post oak savannah of Freestone, Leon, and Limestone counties, Texas. The project area straddles the divide between the Navasota River valley on the west and the Trinity River valley on the east and lies at the western margin of the Caddoan area. Although residential use of the area by the caddo has not been documented, many sites have yielded small quantities of Caddoan pottery, and it is likely that cultures indigenous to the region were affected by the development of caddoan culture not far to the east. For reference, the George C. Davis Site (41CE19) lies only $95 \mathrm{~km}$ to the east-northeast. In addition to contributing information about the interaction between caddoan and neighboring groups in the central part of East Texas, the Jewett Mine sites, by virtue of their location in the Eastern Woodlands but outside of the Caddoan area proper, have the potential to shed light on such topics as regional caddoan settlement systems and the origins of caddo culture.

The operators of the Mine, Northwestern Resources Co., and its customer, Utility Fuels, Inc. have undertaken 17 cultural resources projects since 1979 in the process of supplying lignite to Houston Power and Light's Limestone Station. As a result of these efforts, some 20,000 acres have been surveyed, 180 sites with prehistoric components and 126 sites with historic components have been recorded, 26 prehistoric and 22 historic sites have been tested or otherwise assessed for National Register eligibility, and 5 prehistoric and 2 historic sites have seen mitigative excavations. A project currently in progress entails data recovery excavations at three additional prehistoric sites and one historic site, as well as testing at one prehistoric and five historic sites. These projects have been done by four organizations: Prewitt and Associates, Inc., the Archaeology Research Program at Southern Methodist University, Texas A\&M University, and Espey, Huston and Associates, Inc. Prewitt and Associates, Inc. has preformed all of the work at prehistoric sites and some of the historical investigations since 1984. Since 1987, the bulk of the work at historic sites has been undertaken by Southern Methodist University.

of greatest relevance to Caddoan archeology are recently completed excavations and analyses of three prehistoric sites-Charles Cox (41LN29A), Lambs Creek Knoll (41LN106), and Buffalo Branch (41FT311) -- accompanied by limited reanalysis of the two previously excavated sites at the Mine. The excavations at the three sites consisted chiefly of block excavations covering some $170 \mathrm{~m}^{2}$ and containing ca. $215 \mathrm{~m}^{3}$ of sediment. Approximately 34,000 artifacts were recovered, and 41 cultural features were recorded. As a result of the work at these and other sites in the project area, 70 radiocarbon assays have been obtained, all but 5 of which date to the last 4,000 years. 
The Charles cox site was occupied repeatedly during much of the Archaic period, as well as during the Woodland and Late Prehistoric periods. The Lambs Creek Knoll Site was used predominantly during the late Archaic, Woodland, and Late Prehistoric periods, although a late Paleoindian/early Archaic component is also present. The occupations of the Buffalo Branch Site date chiefly to the late Archaic, Woodland, and early Late Prehistoric periods. Analyses of the data from the five excavated sites at the Jewett Mine indicate that the archeological record of the region reflects occupations by mobile hunter-gatherers adapted to woodland environments.

The bulk of the record dates to the late Holocene Epoch, and it appears that aboriginal groups operated primarily within forager-oriented settlement and subsistence systems for most of this time period. Late Archaic and Woodland groups followed a pattern of high intraregional residential mobility, and the settlement system appears to have incorporated an important logistical component involving procurement of nonlocal lithic materials, probably from central Texas. While this particular logistical component did not change much during later occupations, it does appear that the Jewett Mine region came to be used less for residential purposes and more for resource procurement/processing during the Late Prehistoric period. This shift to a collector-oriented strategy among local groups may reflect increased pressures on land use or increased intergroup conflict brought on by the development of caddoan cultures to the east.

Hunter-gatherer settlement systems prior to the late Holocene are more poorly understood, apparently because midHolocene erosion removed such early deposits over much of the area. The little evidence that does exist, however, suggests that the project area saw limited use for residential purposes during the early to middle Archaic period, perhaps representing increased use of nearby riverine settings where subsistence resources were relatively less affected by Altithermal climatic changes. In contrast, use of the area by late Paleoindian/early Archaic hunter-gatherers may have been more for residential purposes within forager-oriented systems, and there is some evidence that these early groups were more highly mobile on an extraregional scale than later groups. The existing data from the Mine suggest that, regardless of these changes in settlement strategies, population densities increased consistently and/or group territories decreased in size through time in east-central Texas. 